\title{
Optimization of Enzymatic Extraction of Oil from Pistacia Khinjuk Seeds by Using Central Composite Design
}

\author{
Ahmadi Mojtaba*, Karimi Fardin \\ Chemical Engineering Department, Faculty of Engineering, Razi University, Kermanshah, Iran \\ *Corresponding author: m_ahmadi@razi.ac.ir
}

Copyright $@ 2013$ Horizon Research Publishing All rights reserved.

\begin{abstract}
The central composite design (CCD) technique was used to study the enzymatic extraction of oil from pistacia khinjuk seeds by protease and $\alpha$-amylase. The Temperature (A) (i.e., 40,50 and $60^{\circ} \mathrm{C}$ ), $\mathrm{pH}$ (B) (i.e., 4, 6.5 and 9) and reaction time (C) (i.e., 4, 12 and 20) were considered as independent variables. The influence of these three regressors on percentage of oil recovery from seed was evaluated using second-order polynomial multiple regression model. Analysis of variance (ANOVA) showed a high coefficient of determination (R2) value of 0.99 , thus ensuring a satisfactory adjustment of the regression model with the experimental data. The positive sign for the coefficient of $\mathrm{pH}$ and time in the model indicated that the percentage of oil recovery increased with increased levels of those factors. The negative effect of temperature on the oil recovery indicated that the response levels decreased as A increased. The positive sign for the coefficient of the interaction between two factors $\mathrm{B}$ and $\mathrm{C}$ on the response indicated that a simultaneous increase in the $\mathrm{pH}$ and the reaction time led to an increase in that response. An Optimum condition for this process was obtained based on the enzymatic extraction of pistacia khinjuk seeds by protease in the experiment where the temperature was $59.5^{\circ} \mathrm{C}$ and the $\mathrm{pH}$ and time reaction were at high level and oil extraction recovery $58.79 \%$ and the optimum parameters for oil extraction with $\alpha$-amylase are as follows: temperature $52.43^{\circ} \mathrm{C}, \mathrm{pH} 7.5$, reaction time $20 \mathrm{~h}$ and oil extraction recovery $66.83 \%$.
\end{abstract}

Keywords Pistacia Khinjuk, Seed Oil, Enzymatic Extraction, Protease, Central Composite Design and Response Surface Methodology

\section{Introduction}

Pistacia is a genus of flowering plants and belongs to the family Anacardiaceae[1], which comprises 11 species[2]. Among them, Pistacia vera L., Pistacia atlantica subsp. mutica (Fisch. \& C. A. Mey.) Rech. f. (Pistacia mutica), and Pistacia khinjuk Stocks, are the species that occur in Iran [3], which only $\mathrm{P}$. vera has economical importance and its cultivation, as a traditional nut crop, is extended to the dry land areas of the country. P. vera and P. khinjuk are the most primitive species and also postulated that $\mathrm{P}$. khinjuk was directly descended from P. vera [2] as a bridge to other Pistacia species

The world's largest producer of Pistacia spp. was Iran, with over $44 \%$ of world production Most of the production is from orchards that account for $53 \%$ of world planted, but there are a few places, such as in the Zagros Mountains, where wild pistachio persists in natural and extensively managed (i.e., semi-natural) stands[3]. They are the most important types of pistachio and for this reason, Iran is known as the origin of pistachios. Therefore the Pistacia khinjuk seed would be as a novel source of the plant oil for the pharmaceutical industries. The essential oil obtain of P. khinjuk seed showed antihelminthic effect against protoscoleces of E. granulosus and anti-echinococcal activity. The oil from plant seeds is conventionally extracted by either mechanical pressing or solvent extraction $[4,5]$. Mechanical pressing is very in efficient process, leading low oil recovery. In spite of highe efficiency of Solvent Extraction (SE) while is in the $90-98 \%$ range this method suffers from poor quality of protein in oil cake (meal), and high investment, and energy requirements. The commercial sovent for SE process is hexane which is listed among hazardous air pollutants associated with neurological and respiratory disorders on prolonged exposure (the International Standard Organization permits only $50 \mathrm{ppm}$ residual hexane in oil seed meal)[6]. Hence, there is a need to explore alternative safe and efficient oil extraction processes.

Aqueous enzymatic extractions are potentially used to the oil industries due to their high specificity and low operating temperatures. These are the reasons which makes enzyme process more economical for oil extraction processes[7]. The enzymes break down the cell structure of plants. The cell wall of plants consists mainly of pectic substances, cellulose, hemicelluloses, lignin and protein, whereas lipid bodies are enveloped in a lipoprotein layer. Hydrolyses enzymes like cellulose, himicellulase and pectinase break down the cell, while proteases permeabilize the liposome membrane and facilitate oil release from the oil body [7, 8]. Aqueous 
enzymatic oil extraction is one such alternatives-friendly process based on simultaneous isolation of oil and protein from oil seed by dispersing finely ground seed in water and separating the dispersion by centrifugation into oil, solid, and aqueous phases. Dobozi et al. reported treatment of mustard seeds with cellulolytic enzymes results in an increase $(20-30 \%)$ in the yield of oil[9]. Optimization of the enzymatic treatment during aqueous oil extraction with cellulases from sunflower seeds has been reported by Sineiroa et al. [10]. Latifa et al reported oil and protein extraction from sesame seeds during an enzyme-assisted aqueous extraction process[11].Extraction oil from watermelon seeds by aqueous enzymatic extraction method has been studied by Sui et al. and obtaind the optimum parameters form single-factor experiments and response surface methodology[12].Najafian et al found that oil extraction from olive can be enhanced by enzyme hydrolysis and demonstrated that pre extraction enzyme digestion increases cellular degradation and significantly increases oil recovery upon extraction[13]. A aqueous enzymatic extraction of peanut oil and protein has been studied by Jian et al[14]. Hadj-Taieb et al has ben studied the effect of enzymatic formulation on Tunisian olive oil extraction yields[15]. Also optimization of the aqueous enzymatic extraction of pine kernel oil by response surface methodology and extraction of olive oil using enzymatic formulations during malaxation has been reported[16].

In the present work, a CCD in the form of a 23 full factorial design was used to develop mathematical equations, in terms of the oil recovery, providing quantitative evaluation of aqueous enzymatic oil extraction from Pistacia khinjuk. Temperature, $\mathrm{pH}$ and reaction time as the key parameters affecting the extraction process were studied in this evaluationlanguage throughout the text.

\section{Materials and Methods}

\subsection{Materials and Chemicals}

Pistacia Khinjuk seeds were purchased from local market in Iran. The seeds wrapped in plastic bags and stored at $4{ }^{\circ} \mathrm{C}$ until use. Seeds were ground and screened to select the fraction size. All the chemicals used were from Merck (Darmstadt, Germany) or Sigma-Aldrich (Buchs, Switzerland). Protease and $\alpha$-amylase preparation from Aspergillus satoi and Bacillus subtillis, respectively were obtain from Sigma.

All of these enzyme preparations were used without any further purification

\subsection{Aqueous Extraction of Pistacia Khinjuk}

Pistacia Khinjuk was dispersed in distilled water at to make slurry at a ratio of $1: 6 \mathrm{w} / \mathrm{v}$ using a flask. Slurry $\mathrm{pH}$ was adjusted to the desired value with $0.1 \mathrm{~N} \mathrm{NaOH}$ or $0.1 \mathrm{~N} \mathrm{HCl}$, and was stirred on a magnetic stirrer at $250 \mathrm{rpm}$ for $30 \mathrm{~min}$.
Then the enzymes were added in various amounts, and the samples were incubated at various temperatures time, and with some speed of mixing, then samples incubated at constant temperatures. A shaker-incubator (DK-S1060, DAIKI SCIENCE CO.) was used for temperature-controlled shaking of the sample solutions, followed by centrifugation (10000g, $30{ }^{\circ} \mathrm{C}$ ) for $20 \mathrm{~min}$ (MIKRO 200, HETTICH) yielding three distinct phases (i) an oil phase, (ii) creamy phase and (iii) aqueous phase. The upper oil layer was separated and weighed. Oil recovery was expressed relative to that obtained by Soxhlet extraction with hexane.

$\%$ oil recovery $=($ weight of oil extracted $\times 100) /($ total weight of oil estimated by soxhlet method)

The total amount of extracted oil was determined with Soxhlet apparatus following the standard AOAC standard procedure [17]. All experiments were repeated three times to render mistakes during experiments.

\subsection{Experimental Design and Data Analysis}

As shown in Table 1 a CCD in the form of 23 full factorial designs was used. The first eight treatment combinations form a 23 factorial design. The next six treatment combinations are referred to the axial runs, because they lie on the axes defined by the design variables. The last treatment combination represents the center run and this arrangement of CCD is in such a way that allows the development of the appropriate empirical equations (second order polynomial multiple regression equations) $[18,19]$.

$$
\mathrm{y}=\beta_{0}+\beta_{1} \mathrm{~A}+\beta_{2} \mathrm{~B}+\beta_{3} \mathrm{C}+\beta_{11} \mathrm{~A}^{2}+\beta_{22} \mathrm{~B}^{2}+\beta_{33} \mathrm{C}^{2}+\beta_{12} \mathrm{AB}+\beta_{13} \mathrm{AC}+\beta_{2}
$$

The predicted response (y) was therefore correlated to the set of regression coefficients $\left(\beta_{\mathrm{s}}\right)$ : the intercept $\left(\beta_{0}\right)$, linear $\left(\beta_{1}\right.$, $\left.\beta_{2}, \beta_{3}\right)$, interaction $\left(\beta_{12}, \beta_{13}, \beta_{23}\right)$ and quadratic $\left(\beta_{11}, \beta_{22}, \beta_{33}\right)$ coefficients. The "Design expert" (version 5) and "Statistica" (version 5) softwares were used for regression and graphical analyses of the obtained data.

\section{Result and discussion}

\subsection{Effect of Hydrolysis Time on Oil Recovery}

Enzymatic extraction Pistacia Khinjuk seeds with protease and $\alpha$-amylase were subjected to different times (4-24hr) of incubation. The effect of different times of incubation on the recovery oil from Pistacia seed is given in Figure.1. The results show that the oil recovery increased with prolonged enzymatic extraction time and after 16 hour the increase was not significant. The results show that the oil recovery from seed with aqueous enzymatic extraction by protease and $\alpha$-amylase was $51.5 \%$ and $54.6 \%$ respectively for incubation over $16 \mathrm{hr}$ with only as light increase in oil recovery. As can be seen, the oil recovery of seed with $\alpha$-amylase which showed a much higher rate of oil recovery compared to protease. Maximum percentage oil recovery 
with protease was $52.65 \%$ whereas with $\alpha$-amylase was $54.94 \%$ respectively. The oil recovery from seeds with enzymatic oil extraction by $\alpha$-amylase was more than protease because hydrolyze enzyme like $\alpha$-amylase break down the carbohydrate material in cell, while proteases permeabilize the liposome membrane and facilitate oil release from the oil body. Similar observations have been reported by others $[14,20]$ and [6]. It has been reported also elsewhere that the reaction time of the enzymatic extraction process were about $18 \mathrm{~h}$ as an optimal time required for extraction [20].Sharma et al showed that the minimum incubation time to achieve maximum oil recovery from rice bran by enzyme-assisted aqueous extraction was about 18 $\mathrm{h}[6]$.

Table 1. Arrangement of the Central Composite Design for the three independent variables used in the present study

\begin{tabular}{|c|c|c|c|c|c|}
\hline Experiments no. & Temperature (A) & $\begin{array}{l}\mathrm{pH} \\
\text { (B) }\end{array}$ & Reaction time(C) & protease & Amylase \\
\hline 1 & -1 & -1 & -1 & 18.19 & 21.30 \\
\hline 2 & 1 & -1 & -1 & 20.52 & 24.11 \\
\hline 3 & -1 & 1 & -1 & 22.09 & 28.27 \\
\hline 4 & 1 & 1 & -1 & 25.68 & 31.68 \\
\hline 5 & -1 & -1 & 1 & 22.8 & 57.27 \\
\hline 6 & 1 & -1 & 1 & 26.11 & 59.81 \\
\hline 7 & -1 & 1 & 1 & 54.51 & 60.04 \\
\hline 8 & 1 & 1 & 1 & 58.78 & 65.07 \\
\hline 9 & -1 & 0 & 0 & 36.43 & 47.22 \\
\hline 10 & 1 & 0 & 0 & 41.18 & 51.10 \\
\hline 11 & 0 & -1 & 0 & 22.31 & 45.42 \\
\hline 12 & 0 & 1 & 0 & 45.86 & 52.12 \\
\hline 13 & 0 & 0 & -1 & 21.18 & 34.59 \\
\hline 14 & 0 & 0 & 1 & 38.08 & 65.90 \\
\hline 15 & 0 & 0 & 0 & 35.45 & 52.32 \\
\hline 16 & 0 & 0 & 0 & 35.09 & 52.03 \\
\hline
\end{tabular}

The actual variables were 40,50 , and $60^{\circ} \mathrm{C}$ for temperature; $4,6.5$ and 9 for $\mathrm{pH}$ and 4,12 , and $20 \mathrm{~h}$ for reaction time. These were based on the variables levels which coded as $-1,0$, and +1 .
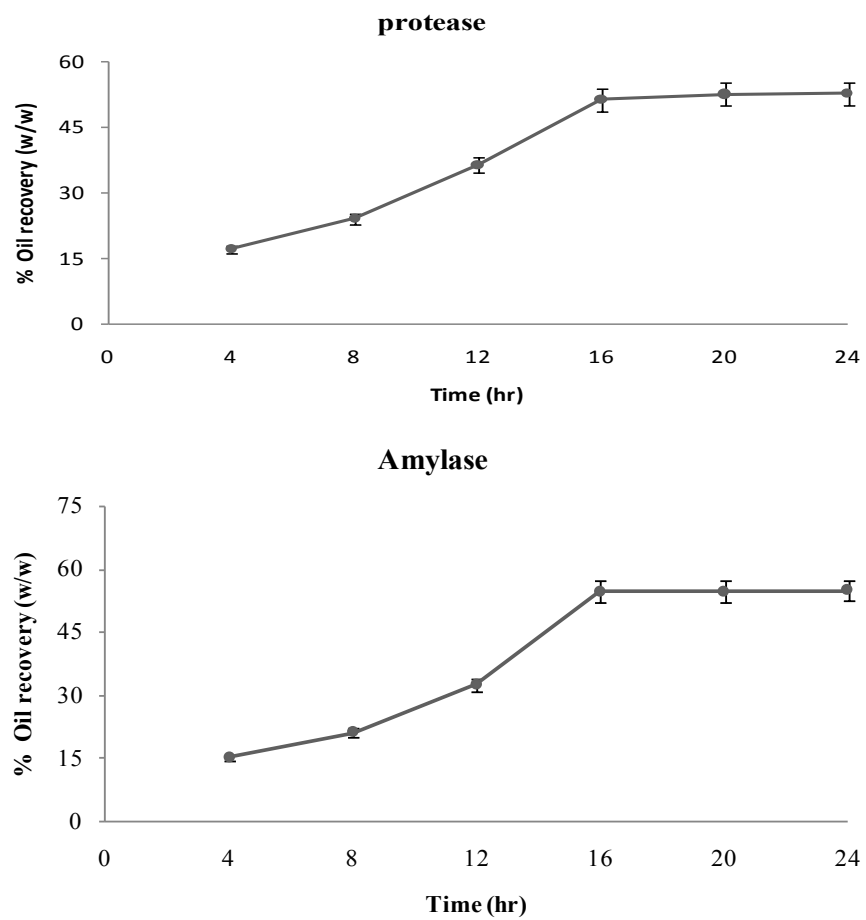

Figure 1. Effect of incubation time on oil recovery by enzymatic aqueous extraction of Pistacia khinjuk $\left(\mathrm{pH} 8,60^{\circ} \mathrm{C}, 80 \mathrm{rpm}\right)$ 
Table 2. ANOVA of the fitted models for the oil recovery

\begin{tabular}{|c|c|c|c|c|c|c|}
\hline & Source & $\mathrm{SS}^{\mathrm{a}}$ & $\mathrm{DF}^{\mathrm{b}}$ & $\mathrm{MS}^{\mathrm{c}}$ & F-value & Prob $>F$ \\
\hline & Model & 2339.03 & 6 & 389.84 & 168.57 & $<0.0001$ \\
\hline & Residual & 20.81 & 9 & 2.31 & & \\
\hline & Lack of Fit & 20.75 & 8 & 2.59 & 40.03 & 0.1217 \\
\hline \multirow[t]{7}{*}{ protease } & Pure Error & 0.065 & 1 & 0.065 & & \\
\hline & Total & 2359.85 & 15 & & & \\
\hline & $\mathrm{R}^{2}$ & 0.991 & & & Adj- $R^{2}$ & 0.985 \\
\hline & C.V\% & 4.64 & & & PRESS & 58.78 \\
\hline & Model & 3139.57 & 7 & 448.51 & 616.54 & $<0.0001$ \\
\hline & Residual & 5.82 & 8 & 0.73 & & \\
\hline & Lack of Fit & 5.78 & 7 & 0.83 & 19.63 & 0.1721 \\
\hline \multirow[t]{4}{*}{ Amylase } & Pure Error & 0.042 & 1 & 0.042 & & \\
\hline & Total & 3145.39 & 15 & & & \\
\hline & $\mathrm{R}^{2}$ & 0.998 & & & Adj- $R^{2}$ & 0.996 \\
\hline & C.V\% & 1.82 & & & PRESS & 27.06 \\
\hline
\end{tabular}

${ }^{\mathrm{a}} \mathrm{SS}$ : sum of squares $\quad{ }^{\mathrm{b}} \mathrm{DF}$ : degree of freedom $\quad{ }^{\mathrm{c}} \mathrm{MS}$ : Mean squares

\subsection{Influence on Oil Recovery of Different Ph}

In order to assess the effect of $\mathrm{pH}$ on oil recovery, the protease and $\alpha$-amylase enzymatic extraction was carried out at different $\mathrm{pH}$ values in the range of 4-9 by adding desired amount of $\mathrm{HCl} 0.1 \mathrm{~N}$ or $\mathrm{NaOH} 0.1 \mathrm{~N}$ into the slurry. The temperature of extraction was kept at $60^{\circ} \mathrm{C}$ since the enzyme preparations used are reported to be stable up to this temperature. Figure 2 shows the effect of varying the amount of $\mathrm{pH}$ on oil recovery. The results indicate that oil recovery of seed with aqueous enzymatic extraction by $\alpha$-amylase increased along with the increase in $\mathrm{pH}$. While for extraction by using protease with the increase in $\mathrm{pH}$, there was initial increase in oil recovery before slightly decreasing.

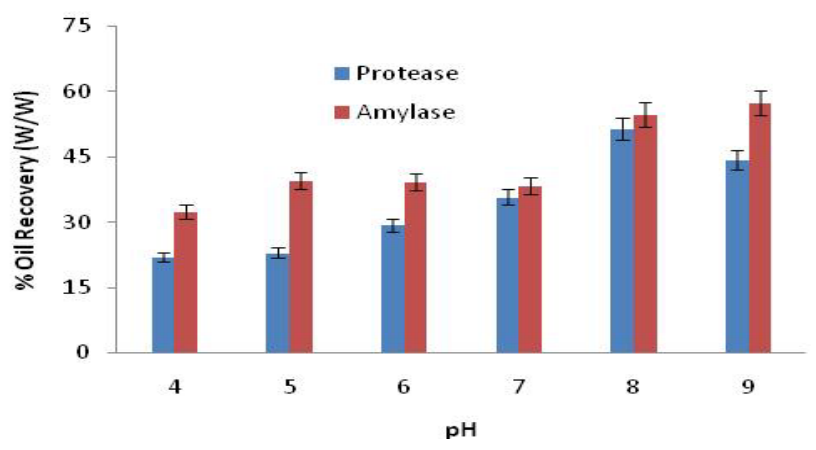

Figure 2. Effect of $\mathrm{pH}$ on enzymatic oil extraction from Pistacia khinjuk seeds. The enzyme mixture was then incubated overnight at $60^{\circ} \mathrm{C}$ with constant shaking at $80 \mathrm{rpm}$.

\subsection{Central Composite Design and Fitted Regression Models as Related to the Oil Recovery}

The fit summary for the oil recovery suggests the quadratic relationship where the additional terms are significant and the model is not aliased. The ANOVA table of the quadratic model with other adequacy measures $\mathrm{R}^{2}$ and adjusted $\mathrm{R}^{2}$ are given in Table 2 . The associated p-value of less than 0.05 for the model (i.e., $\alpha=0.05$, or $95 \%$ confidence level) indicates that the model terms are statistically significant. The coefficient of variance $(\mathrm{CV})$ has been found to be (\%): 4.64 and 1.82 for enzymatic extraction with protease and $\alpha$-amylase respectively.

The $\mathrm{CV}$ as the ratio of the standard error of estimate to the mean value of the observed response (as a percentage) is a measure of reproducibility of the model and as a general rule a model can be considered reasonably reproducible if its CV is not greater than $10 \%$ [18]. The lack-of-fit value of the model indicates non-significance, as this is desirable. The ANOVA result shows that temperature, $\mathrm{pH}$, reaction time, the quadratic effect of temperature and reaction time, along with the interaction effect of $\mathrm{pH}$ and reaction time is the significant model terms associated with the oil recovery from Pistacia Khinjuk seeds with protease. For enzymatic extraction with $\alpha$-amylase in addition to the above effects, the quadratic effect of $\mathrm{pH}$ is the significant. The other model terms are not significant and thus, eliminated by backward elimination process to improve model adequacy.

The ANOVA table for the reduced quadratic model is shown in Table 2. The reduced model results indicate that the model is significant (p-value less than 0.05). The other adequacy measures $R^{2}$ and adjusted $R^{2}$ are in reasonable agreement and are close to 1 , which indicate adequacy of the model. The adequate precision compares the signal-to-noise ratio and a ratio greater than 4 is desirable [21]. The value of adequate precision ratio for enzymatic extraction with protease and $\alpha$-amylase of 41.33 and 76.06 respectively, indicates adequate model discrimination. The lack-of-fit f-value of 40.03 and 19.63 implies that the 
lack-of-fit is not significant relative to the pure error.

The final mathematical models for aqueous enzymatic oil extraction with protease and $\alpha$-amylase in terms of coded Factors, which can be used for prediction within same design space, are given as follows:

Protease:

$\%$ oil reovery $=35.16+1.83 \mathrm{~A}+9.7 \mathrm{~B}+9.26 \mathrm{C}+$ $6.92 \mathrm{BC}+2.67 \mathrm{~A}^{2}-6.51 \mathrm{C}^{2}$

$\alpha$-amylase $\%$ oil reovery $=52.28+1.77 \mathrm{~A}+2.93 \mathrm{~B}+$ $16.81 \mathrm{C}-0.81 \mathrm{BC}-3.17 \mathrm{~A}^{2}-3.56 \mathrm{~B}^{2}-2.09 \mathrm{C}^{2}$

\subsection{Effects of Process Parameters on the Responses}

In the perturbation plot, Figure. 3 shows the effects when all factors at the center point in the design space are compared. The perturbation plot assists in comparison of the effects of all factors at a particular point in the design space; when the factor curvature is sharper, the factor effect is more important to the response. The plot was obtained for $50^{\circ} \mathrm{C}$ temperature, $6.5 \mathrm{pH}$ and 12 hour of reaction time

Figure 3 shows that the response of the oil recovery with protease was very sensitive to $\mathrm{pH}$, followed by the reaction time and finally, by temperature. The oil recovery with $\alpha$-amylase was very sensitive to reaction time, followed by $\mathrm{pH}$ and temperature. For a model to be reliable, the response should be predicted with a reasonable accuracy by the model when compared with the experimental data

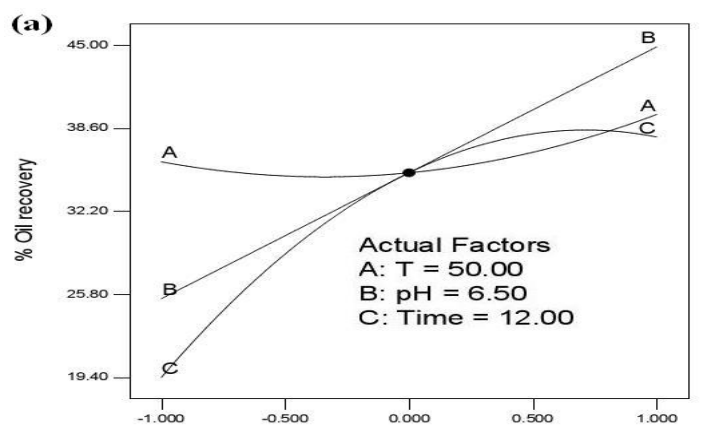

Deviation from Reference Point (Coded Units)

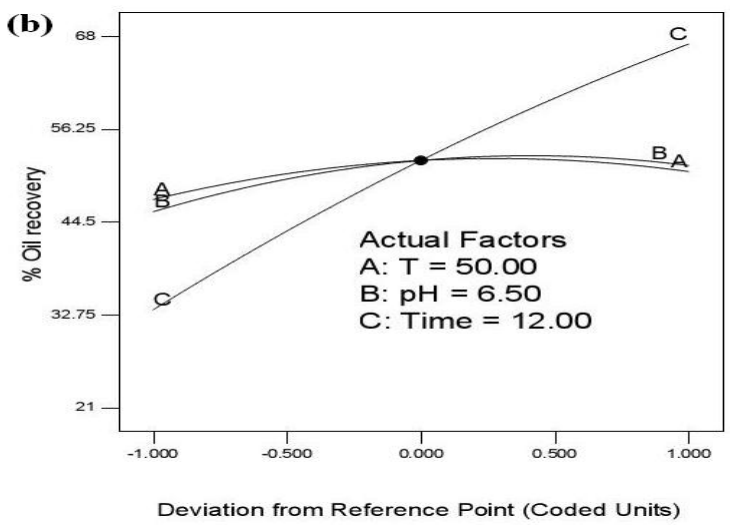

Figure 3. Perturbation graph showing the effect of each of the independent variables on oil recovery while keeping other variables at their respective mid-point levels. (A) Temperature, (B) $\mathrm{pH}$ and (C) Reaction time. (enzymatic extraction by (a): protease and (b): $\alpha$-amylase)

\subsection{Response Surface Plotting and Extraction Process Optimization Based on the Oil Recovery}

For graphical interpretation of the interactions between regressor variables, use of surface plots of the regression equation is highly recommended $[18,19]$. Interaction implies that effect produced by changing one factor level (for example $\mathrm{pH}$ ) depends on the level of the other factor. In the fitted model for oil recovery, interaction of $\mathrm{B}(\mathrm{pH})$ and $\mathrm{C}$ (reaction time) was statistically significant. Figure 4 shows the dependence of oil recovery by protease on both the $\mathrm{pH}$ and reaction time, when temperature was at an optimum condition $\left(59.5^{\circ} \mathrm{C}\right)$. In enzymatic aqueous extraction oil from Pistacia khinjuk by protease, at low level of $\mathrm{pH}$ the oil recovery increase with increasing level of reaction time from its low level to middle level, hereafter the response decreases. At high level of $\mathrm{pH}$ increasing level of reaction time from its low level to high level the oil recovery increases. Also at a given $\mathrm{pH}$, increasing level of the reaction time the response increases.
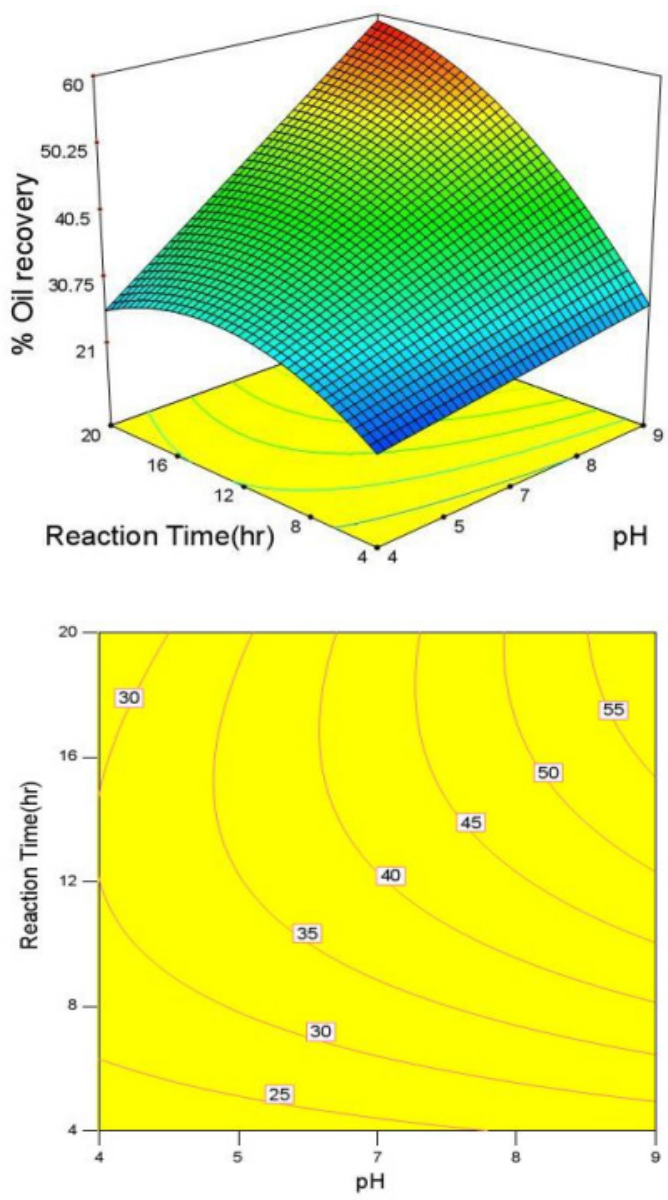

Figure 4. Response surface and contour plots for the effect of reaction time and $\mathrm{pH}$ on the oil recovery, $\left(\mathrm{T}=59.5^{\circ} \mathrm{C}\right)$, protease

The effect of $\mathrm{pH}$ and reaction time on the oil recovery by $\alpha$-amylase at fixed temperature at $52.43^{\circ} \mathrm{C}$ (the optimum temperature) was shown in Figure 5.There was significant interaction between $\mathrm{pH}$ and reaction time. The $\mathrm{pH}$ has a slightly positive effect on the oil recovery. Similar result was 
also reported by Jiang et al. that found $\mathrm{pH}$ significantly affected peanut oil recovery using enzymatic extraction with an increase in $\mathrm{pH}$, there was increase in oil yields recovery. $\mathrm{pH}$ affected on kinetics enzyme activity [14]. Addition, reaction time positively affects oil recovery throughout the experiment. In the models for the oil recovery, $\mathrm{C}$ was identified as the major regressor variable affecting the responses (greatest coefficients, $\mathrm{C}=16.81$ ) and oil recovery increases almost linearly as reaction approaches its peak (at $20 \mathrm{hr}$ ). Studies reported elsewhere with oil recovery from seed by using enzymatic extraction showed that there was significant interaction between temperature and reaction time. Generally, reaction time has a positive effect on the oil yield [22].
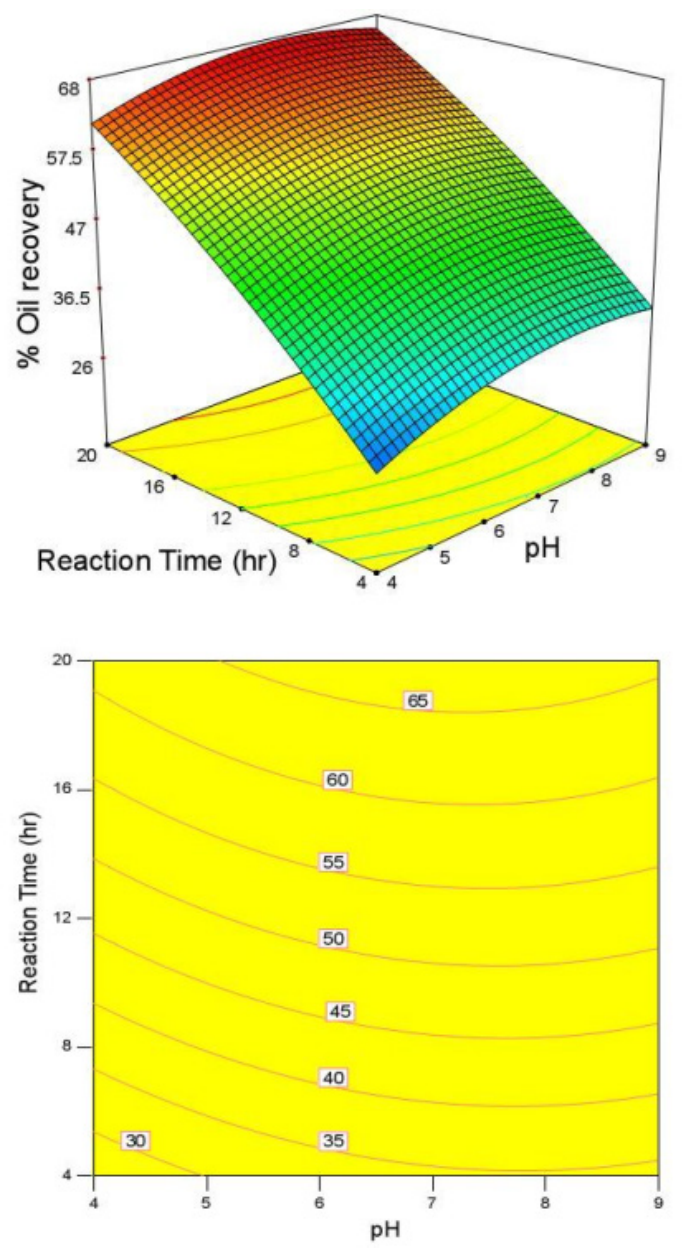

Figure 5. Response surface and contour plots for the effect of reaction time and $\mathrm{pH}$ on the oil recovery, $\left(\mathrm{T}=52.43^{\circ} \mathrm{C}\right), \alpha$-amylase

\section{Conclusions}

In this work the enzymatic Extraction of oil from Pistacia khinjuk seed by protease and $\alpha$-amylase was studied using CCD and RSM. The following conclusions were reached:

- In terms of the changed levels of $\mathrm{pH}$, the oil recovery by protease increased as $\mathrm{pH}$ increased while the reaction time was at $20 \mathrm{hr}$.

- In terms of the changed levels of reaction time, the oil recovery by protease increased as reaction time increased from $4 \mathrm{hr}$ to vicinity of midlevel, thereafter it starts to decrease when $\mathrm{pH}$ was at low level.

- In terms of the changed levels of reaction time, the oil recovery by $\alpha$-amylase increased as reaction time enzymatic process increased from 4 to $20 \mathrm{~h}$.

- The optimum oil recovery condition with protease was achieved by setting the experiment with temperature at $60^{\circ} \mathrm{C}$ while the other two regressor variables, i.e., $\mathrm{pH}$ and reaction time were at 9 and $20 \mathrm{hr}$, respectively.

- Optimum conditions for the enzymatic Extraction of oil from Pistacia khinjuk seed by $\alpha$-amylase be achieved by setting temperature at $52.43^{\circ} \mathrm{C}, \mathrm{pH}$ at 7.49 and reaction time of 19.5 hours.

\section{REFERENCES}

[1] Shuraki, Y.D. and M. Sedgley, Effect of pistil age and pollen parent on pollen tube growth and fruit production of pistachio. J. Hortic. Sci,Vol. 69, 1019-1027, 1994.

[2] Zohary, D., The genus Pistacia, S. Padulosi, T. Caruso, E. Barone, Editors, Taxonomy, distribution, conservation and uses of Pistacia genetic resources. IPGRI, Palermo, Rome Vol., 1-11, 1996.

[3] Razavi, S., Pistachio production, Iran vs. the World. Acta Hortic,Vol. 726, 689-694, 2006.

[4] Tomaino, A., et al., Antioxidant activity and phenolic profile of pistachio (Pistacia vera L., variety Bronte) seeds and skins. Biochimie,Vol. 92 No.9, 1115-1122, 2010.

[5] Mani, S., S. Jaya, and R. Vadivambal, Optimization of Solvent Extraction of Moringa (Moringa Oleifera) Seed Kernel Oil Using Response Surface Methodology. Food and Bioproducts Processing,Vol. 85 No.4, 328-335, 2007.

[6] Sharma, A., S.K. Khare, and N.C. Gangodavilage, Enzyme-Assisted Aqueous Extraction of Rice Bran Oil. Journal of the American Oil Chemists' Society,Vol. 78, $817-821,2001$.

[7] Rosenthal, A., D.L. Pyle, and K. Niranjan, Aqueous and enzymatic processes for edible oil extraction. Enzyme and Microbial Technology,Vol. 19 No.6, 402-420, 1996.

[8] Fullbrook, P., Use of Enzymes in the Processing of Oilseeds. Ibid,Vol. 60, 476-478, 1983.

[9] Dobozi, S., A. Halasz, and K.E. Kovacs, Enhancement of mustard oil yield by cellulolytic pretreatment. Applied Microbiology Biotechnology,Vol. 29 No.1, 39-43, 1988.

[10] Sineiro, J., et al., Optimization of the enzymatic treatment during aqueous oil extraction from sunflower seeds. Food Chemistry Vol. 61 No.4, 467-474, 1998.

[11] Latif, S. and F. Anwar, Aqueous enzymatic sesame oil and 
protein extraction. Food Chemistry,Vol. 125 No.2, 679-684, 2011.

[12] Xiaonan, S., et al., The research on extracting oil from watermelon seeds by aqueous enzymatic extraction method. Procedia Engineering,Vol. 15, 4673-4680, 2011.

[13] Najafian, L., et al., Aqueous extraction of virgin olive oil using industrial enzymes. Food Research International,Vol. 42 No.1, 171-175, 2009.

[14] Jiang, L., et al., Aqueous enzymatic extraction of peanut oil and protein hydrolysates. Food and Bioproducts Processing, Vol. 88 No.2-3, 233-238, 2010.

[15] Hadj-Taieb, N., et al., Optimisation of olive oil extraction and minor compounds content of Tunisian olive oil using enzymatic formulations during malaxation. Biochemical Engineering Journal,Vol. 62 No.0, 79-85, 2012.

[16] Yang, L., et al., Optimization of the aqueous enzymatic extraction of pine kernel oil by response surface methodology. Procedia Engineering,Vol. 12, 4641-4652, 2011.
[17] Horowitz, W., of Analysis of the Association of Official Analytical Chemists, ed. A.o.O.A. Chemists. Washington, DC, 1984.

[18] Lapin, L.L., Modern Engineering Statistics, 1997, Wards worth Publishing Company: Belmont, CA, USA.

[19] Vining, G.G., Statistical Methods for Engineers. London 1V7AA Duxburg Press, An International Thomason Publishing, 2003.

[20] Sharma, A., S.K. Khare, and M.N. Gupta, Enzyme-Assisted Aqueous Extraction of Peanut Oil. Journal of the American Oil Chemists' Society,Vol. 79 No.3, 215-218, 2002.

[21] Beg, Q., V. Sahai, and R. Gupta, Statistical media optimization and alkaline protease production from Bacillus mojavensis in a bioreactor. Process Biochemistry,Vol. 39, 203-209, 2003.

[22] Li, Y., Jiang, L., Sui, X., and Wang, S., Optimization of the aqueous enzymatic extraction of pine kernel oil by response surface methodology. Procedia Engineering, Vol. 15 NO.0, 4641-4652, 2011. 